
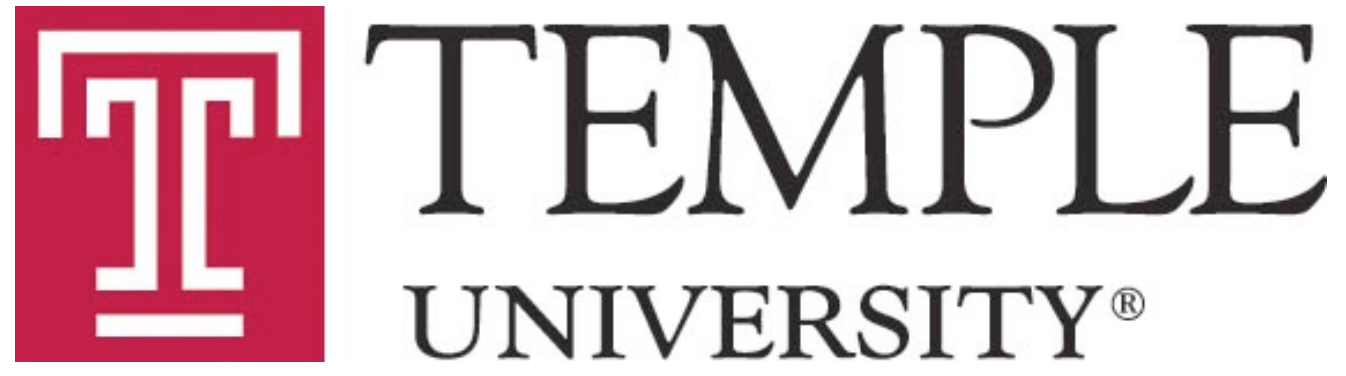

\title{
Are Sunk Costs Irrelevant? \\ Evidence from Playing Time in the National Basketball Association
}

by

Daniel Leeds, Michael A. Leeds, and Akira Motomura

Department of Economics

DETU Working Paper 13-04

November 2013

1301 Cecil B. Moore Avenue, Philadelphia, PA 19122

http://www.cla.temple.edu/economics/faculty/detu-working-paper-series/ 
November 2013

\title{
Are Sunk Costs Irrelevant?
}

\section{Evidence from Playing Time in the National Basketball Association}

\author{
Daniel Leeds \\ University of Michigan \\ dleeds@umich.edu \\ Michael A. Leeds \\ Temple University \\ mleeds@temple.edu \\ Akira Motomura \\ Stonehill College \\ amotomura@stonehill.edu
}

A previous version of this paper was presented at the Western Economic Association International Annual Meetings in Portland, OR. 
Sunk Costs and the NBA, November 2013, p. 2

\section{Introduction}

"Sunk costs are irrelevant," is one of the most commonly recited mantras of any price theory class. Still, no matter what diagrams we draw or calculus we show, students seldom believe this claim - and for good reason. Political and corporate leaders alike appeal to sunk costs as a justification for future policies. Economic experiments (e.g., Khan, Salter, and Sharp (2000)) have also found a "commitment effect." As the initial expenditure on a project rises, agents appear willing to spend more to see it through to completion. The relevance of fixed costs is thus one of the key elements of behavioral economics, dating back to seminal work by Thaler (1980) and Tversky and Kahneman (1981).

Most of the evidence regarding the relevance of sunk costs stems from anecdotes or from artificial experiments. We provide a real-world test of the commitment effect by estimating the impact of draft position on playing time in the National Basketball Association (NBA). Whether a team maximizes wins or profits, it should give the greatest playing time to its most productive players regardless of how they were acquired. (For interesting takes on why a rational team might not want to play its best players, see Taylor and Trogdon, 2002 and Price, Soebbing, Berri and Humphries, 2010). However, sports commentators constantly report that teams are committed to specific players because they had used high draft choices or paid high prices to obtain them, a classic application of the commitment effect.

If teams feel such commitment, then they may give first-round draft picks more playing time than they give to players selected in later rounds or signed as undrafted free agents, even after accounting for performance. The abundance of data on productivity and playing time in the NBA allows us to perform just such a test. Our study builds on earlier studies of playing time in the NBA by Staw and Hoang (1995) and by Camerer and Weber (1999). In addition to using a 
Sunk Costs and the NBA, November 2013, p. 3

data set that more accurately reflects player usage, we use a more appropriate technique regression discontinuity $(\mathrm{RD})$ - to estimate the impact of draft position on playing time. We also acknowledge the possible impact of race and ethnicity on playing time by testing for whether any commitment effects are different for African-American players than for players as a whole. ${ }^{1}$ Finally, we account more completely for time lost due to injury, suspension, and other factors than do the previous studies.

The next section of this paper briefly reviews the literature on sunk costs, with particular attention to the work by Staw and Hoang (1995) and Camerer and Weber (1999). The third section explains the relevance of regression discontinuity and presents the empirical model. Section four describes the data and addresses several potential threats to the validity of our RD estimates. The fifth section presents and discusses our results. The sixth section concludes.

\section{The Behavioral Economics of Sunk Costs}

The importance of sunk costs has been a source of conflict between economists and psychologists. Standard neoclassical theory claims that because sunk costs affect neither marginal benefit nor marginal cost they should have no bearing on our choices. However, Thaler (1980) and Tversky and Kahneman (1981) cite psychology studies dating back to the 1950s showing that subjects take previous expenditures of money or effort into account when making decisions. Their findings thus contradict the core neoclassical assumption that agents behave rationally.

\footnotetext{
${ }^{1}$ See Kahn and Scherer (1988), Hamilton (1997), and Bodvarsson and Brastow (1999) for discussions of the impact of race on salary in the NBA. Kanazawa and Funk (2001) provide an interesting treatment of race and playing time in the NBA.
} 
McAfee, Mialon, and Mialon (2010) try to place the apparently irrational attachment to sunk costs in a neoclassical setting. They claim that people account for sunk costs for three economically rational reasons. First, sunk costs might contain information about expectations. If a project has unknown returns, high start-up costs might be a signal that future expenditures could bring a high future income.

Second, because of the signal it sends, responding to sunk costs could have reputational effects. McAfee et al. cite two such effects. Disparate agents sometimes make individual investments, the return on which depends on the overall level of investment. In the presence of network effects, an individual who pre-commits to finishing what he starts might encourage others to invest as well, thereby generating an efficient overall level of investment. In addition, sunk costs might have political effects, as public or private decision-makers might try to conceal poor decisions by continuing to invest in projects on which they have already spent large sums. Although McAfee et al. do not mention it, sending such a signal could be part of an effort to deceive potential purchasers or investors, as has been alleged regarding some financial institutions before and during the financial crisis.

Finally, McAfee et al. note that large sunk costs might lead to state dependence. As sunk costs grow, the resources at the decision-maker's disposal fall. With fewer resources available, the agent could find himself committed to seeing through an action that he would have abandoned if he had more resources at his disposal.

In our context, teams draft players with abundant raw talent, some of whom apply that talent immediately, some of whom never make full use of their talent, and some of whom need playing time to reach their full potential. Highly-drafted players might receive extra playing time because general managers and coaches believe they need more time to develop their abilities. 
Even if they privately believe a player to be a bad investment, they might provide extra playing time to signal that he is a work in progress. They might do this in the hope that other teams believe that the player is a valuable trade commodity and that fans believe that the general manager is thinking about long-term success. Finally, high draft picks command high salaries, leaving less money available to pursue other quality players and forcing coaches to use the roster at their disposal. In 2013-2014, the first player selected in the draft received a salary between $\$ 4.44$ million and $\$ 5.16$ million in his first year, which rises to between $\$ 4.84$ million and $\$ 5.80$ million in his third year. Salaries are lower for later draft picks, with the final choice in the first round receiving between $\$ 880,000$ and $\$ 1.06$ million in his first year. Players chosen in the second round have no specified salaries and no guaranteed contracts. ${ }^{2}$

Despite the controversy over sunk costs and their centrality to the neoclassical-behavioral economics debate, there is very little rigorous empirical analysis of their role in decision-making. One of the few tests - also in the context of the NBA — comes from Staw and Hoang (1995). They used data for players drafted in the first two rounds of the 1980-1986 NBA drafts. ${ }^{3}$ They then ran separate sets of regressions for players with two, three, four, and five years of experience of playing time per season on draft position, performance measures, and other control variables such as race and nationality.

Because they worried that performance variables might be collinear, Staw and Hoang used factor analysis to create three indices for performance: scoring, toughness, and quickness. They also include dummy variables to indicate whether the player was a guard and whether the player was injured during the season in question. Because they felt that teams would be less

\footnotetext{
${ }^{2}$ Numbers taken from "2013-14 NBA Rookie Salary Scale," Hoopsworld, at http://www.hoopsworld.com/2013-14rookie-salary-scale/, viewed October 6, 2013.

${ }^{3}$ At that point, the draft lasted seven rounds. In 1988, the draft was reduced to three rounds, and in 1989 it fell to the present two rounds.
} 
committed to players whom they had not drafted, they added a dummy variable to denote players who had been traded. Draft position was included linearly; the first player selected took a value of one, the second player took a value of two, and so on.

Staw and Hoang find that draft position has a negative and significant impact on playing time, meaning that a player with a lower draft number (picked earlier) gets more playing time. The impact of draft position on playing time falls as NBA experience rises, from 22.8 minutes per draft position per season in year two to 13.8 in year five. Thus the difference in playing time between players chosen first and twenty-ninth (the final first-round pick when their paper was written) decreases from about 638 minutes to 386 from years two to five. Since players rarely play more than 3000 minutes per season, this corresponds to a substantial change in impact. ${ }^{4}$ However, because Staw and Hoang do not provide standard errors or t-statistics, we cannot tell whether the coefficients are significantly different from one another or from zero.

Staw and Hoang propose and reject three explanations based on rational decision making for their findings. First, a team might be stuck with high draft choices due to the rigidities imposed by the NBA's salary cap. They reject this proposal because they claim that teams can always waive (i.e., release) unproductive players and replace them with lower-paid players. ${ }^{5}$ Second, teams might be reluctant to trade high draft choices who are popular among fans. They dismiss this possibility because they claim that fans are notoriously fickle and readily turn on players - such as Adam Morrison, a third overall draft pick of the Charlotte Bobcats - who do not live up to their promise. Finally, they test whether teams are more patient with high draft picks in the expectation that their performance will improve and eventually match expectations.

\footnotetext{
${ }^{4}$ As each season consists of 82 48-minute games, there are a total of 3936 possible minutes of regulation time for each player. Less than $5 \%$ of the player seasons with any positive playing time in our data totaled over 3000 minutes, meaning that very few players play for over $75 \%$ of their potential playing time each season.

${ }^{5}$ The guaranteed contracts that play a role in our analysis were not part of the collective bargaining agreement during the period Staw and Hoang study, though teams may have offered them to players.
} 
Their regressions indicate that draft position is a poor predictor of performance in years 4 and 5 , so letting the original draft number affect later playing time is not justified.

Camerer and Weber (1999) build on Staw and Hoang in several ways. They survey the growth of the commitment literature at the time and conclude that NBA playing time offers the best proxy for a team's commitment to a player. More importantly, they test for greater commitment to first-round picks (and allow for limited nonlinearity) by including a dummy variable for whether a player was a first-round choice. They also control separately for performance in both the current and previous seasons, unbundle Staw and Hoang's three performance indices and use the cost of player trading cards as a proxy for popularity. In the final set of regressions, they replace these observed performance measures with predicted measures. These predictions are based on regressions of future performance on previous performance and draft position.

Camerer and Weber use data from the first two rounds of the 1986-1991 drafts. Their results are sensitive to their specification. Like Staw and Hoang, Camerer and Weber find that draft position has a strong, positive impact on playing time in years two and three of a player's career, with the first player chosen in the first round of the draft playing 320 to 475 more minutes over the course of a season than the first player chosen in the second round. Their results for years four and five are lower than Staw and Hoang's in all specifications, in some cases substantially so. When they use predicted rather than actual performance, playing time increases by almost 30 minutes per draft position for year three but does not have a statistically significant impact in years four and five. ${ }^{6}$ The dummy indicating a first-round selection is insignificant,

\footnotetext{
${ }^{6}$ The point estimate for year 4 is smaller than for years 2 and 3 , but it is not statistically distinguishable from them. The estimate for year 5 is much smaller. The drop in year 5 might result from the fact that rookie contracts last for three years, with a team option for a fourth year.
} 
suggesting no discontinuity in going from round one to round two, in years two and five. In years three and four, it is negative, which runs contrary to Camerer and Weber's expectations.

\section{Empirical Model}

Our model builds on the models of Staw and Hoang (1995) and Camerer and Weber (1999) in several ways. Most importantly, it provides a new application of the regression discontinuity technique. $\mathrm{RD}$ recognizes that small changes in an explanatory variable can have an unusually large impact when it crosses a threshold value. (See Angrist and Pischke, 2008, for a detailed discussion.) Because of the winner-take-all nature of elections, RD studies have largely focused on the impact of vote shares in politics (Lee, 2008) and union recognition (DiNardo and Lee, 2004).

We use RD to analyze NBA teams' commitment to their draft choices. Like Staw and Hoang (1995) and Camerer and Weber (1999), we test for differences between players taken in the first round and those taken in the second round. We also look for differences between "regular" first-round picks and those taken in the NBA lottery. Since 1985, the NBA has used a lottery to determine the draft order of the teams that failed to make the 16-team playoffs in the previous season. The purpose of the lottery is to discourage teams from intentionally losing games late in the season to secure a higher draft pick. ${ }^{7}$ In recent years, the first three picks have been determined by a weighted lottery that gives the team with the worst record a 25 percent chance of receiving the first draft pick, and the non-playoff team with the best record a 0.5 percent chance of receiving that pick. A similar process determines the second and third overall

\footnotetext{
${ }^{7}$ For more on the rationale behind a lottery, see Taylor and Trogdon (2002) and Soebbing and Mason (2009).
} 
picks. The remaining draft picks, beginning with the fourth, are awarded in reverse order of finish.

Our data (described below) show clear differences in the mean experiences of players who were drafted in the first and second rounds and between lottery picks and other first-round picks. Table I shows that, on the extensive margin, first-round picks were, on average, qualitatively different from second-round picks but that lottery picks did not differ much from other first-round picks. First-round draft picks played 1419 player-seasons in our data, with lottery picks accounting for slightly over half this total. This makes sense because just over half the players taken in the first round count as lottery picks.

The first two columns of Table II list the average of the ratio of players' actual playing time to the maximum possible amount of regulation time they could have played, after accounting for such exogenous factors as injuries and suspensions. ${ }^{8}$ The first column shows the unconditional fraction of time played, and the second column shows the fraction of time conditional on a player's having received any playing time. Roughly half of all second-round choices do not play at all, while all first-round choices play. Thus, the unconditional and conditional means differ much more for second-round picks than for first-round picks. These results show that even greater differences exist along the intensive margin. Among players with positive playing time, lottery picks play over half their total possible minutes, other first-round picks play a little more than one-third their possible minutes, and second-round picks play only about one-fourth their possible minutes.

\footnotetext{
${ }^{8}$ In reality, maximum playing time would include all overtimes played. However, overtime represents an extremely small number of minutes each season. For instance, a player who participated in 20 overtime periods (an extremely high number) would see his maximum total minutes increase by approximately $2.5 \%$. This simplification is therefore highly unlikely to qualitatively impact our results.
} 
The last column of Table II show that differences in playing time might reflect differences in ability. For ability, we use wins produced per 48 minutes played (WP48). WP48 uses a vector of individual performance measures, such as points, assists, turnovers, and steals, to explain how many of a team's wins can be attributed to a given player. The value of WP48 at each level is statistically different from the others at the 95 percent level. ${ }^{9}$

A commitment to first-round draft choices can arise for two reasons. First, since the 1995 collective bargaining agreement, a team incurs a qualitatively greater financial commitment to the last player chosen in the first round than it does to the first player chosen in the second round..$^{10}$ As noted above, first-round draft picks receive three-year guaranteed contracts with payment set by a fixed salary scale. The rookie contracts of second-round draft picks are subject to negotiation and are typically for two years at a much lower salary, which is often not guaranteed. Before 1995, all rookie contracts were negotiated between team and player. The top draft picks often received contracts with many more years of guaranteed salary. ${ }^{11}$ Behavioral economists would predict that the greater financial obligation leads teams to give high draft picks more playing time than their performances merit. The 1995 collective bargaining agreement reduced rookie salaries by 30 to 50 percent, which could lessen the overall sunk cost (Krautmann, Von Allmen, and Berri 2009; Rosenbaum 2003).

Second, teams are more psychologically committed to players whom they draft in the first round, as these players are frequently identified as future stars of the franchise. A "wasted" first-round pick could doom a franchise to years of mediocrity. This was the case for the Los

\footnotetext{
${ }^{9}$ For more on wins produced, see Berri, Schmidt, and Brooks (2006) and Berri (2008).

${ }^{10}$ Normally, the number of first round picks equals the number of teams, which was 27 from 1989 through 1994 , 29 from 1995 through 2003, and has since been 30. In several years in our sample period, though, a team lost its first round pick for major violations of league rules in signing players.

${ }^{11}$ The change in the CBA was effectively an attempt to save teams from themselves after Glenn Robinson Jr. signed a 10-year guaranteed \$68 million contract with the Milwaukee Bucks in 1994.
} 
Angeles Clippers, who for many years drafted mediocrities over players who went on to become perennial All Stars. ${ }^{12}$ Such mistakes could easily cost a coach or general manager his job.

Separate analysis of lottery picks provides a way to separate financial commitment from psychological commitment. If teams are more committed to lottery picks than to later first-round choices, that commitment is likely to be psychological rather than financial. The last lottery pick costs a team only about 5 percent more in salary than the first non-lottery pick, which is a much smaller difference than that between first-round and second-round draft picks. Since lottery picks receive more publicity than other first-round picks, fans may place much greater expectations on them than on other choices. Any discontinuity detected at this margin might help us separate the financial from the psychic motivations surrounding first-round picks.

At first glance, Camerer and Weber (1999) appear to use a RD framework by including both draft position and a dummy variable for the round in which a player is selected. However, their model contains only a global linear measure of draft position. In effect, they estimate a step function similar to that shown in Figure 1. They therefore risk modeling a continuous, nonlinear function as a discontinuous, linear function, as seen in Figure 2. Such misspecification attributes the continuous impact of draft position to the discontinuous impact of crossing from lottery to non-lottery status or from the first round to the second.

$\mathrm{RD}$ provides two ways to avoid such misspecification. ${ }^{13}$ One approach is to generalize the global equation to a polynomial in draft position, as in Equation (1):

$$
T_{i t}=\beta_{0}+\beta_{1} d_{i}+\beta_{2} d_{i}^{2}+\cdots+\beta_{k} d_{i}^{k}+\theta^{\prime} Z_{i t}+\delta_{j} D_{j i}+\varphi^{\prime} W_{i}+\varepsilon_{i t}
$$

\footnotetext{
${ }^{12}$ For example, the Clippers chose Lorenzen Wright instead of Kobe Bryant and Michael Olowokandi instead of Dirk Nowitzki. Neither Wright nor Olowokandi played in an All Star game. Bryant has been to 15 All Star Games and won the 2007-08 Most Valuable Player Award. Nowitzki has been to 11 All Star Games and won the 2006-07 Most Valuable Player Award.

${ }^{13}$ For a detailed analysis, see Angrist and Pischke (2008).
} 
Where $T_{i t}$ is the playing time of player $i$ in season $t, d_{i}$ is player $i$ 's draft position, $Z_{i t}$ is a vector of control variables, $D_{j i}$ are dummy variables indicating whether a player was selected in the first round $(j=1)$ or in the draft lottery $(j=L)$, and $W_{i}$ captures the interaction between draft position and the relevant dummy variable. ${ }^{14}$ The player's draft position is captured by the variable $d_{i}$, which can range from 1 to 60 . The polynomial allows draft position to have a nonlinear impact on playing time, with the dummy variable picking up any remaining discontinuity.

While a global polynomial is superior to global linear estimation, it can be affected by points that are far from the threshold and therefore have no bearing on the discontinuity. To capture behavior in the relevant segment of the sample, one can apply local linear regression, such as that in Equation (2)

$$
T_{i t}=\gamma_{0}+\gamma_{1} D_{j i}+\gamma_{2} \widetilde{d}_{l}+\gamma_{3} D_{j i} \widetilde{d}_{l}+\gamma^{\prime} Z_{i t}+v_{i t}
$$

Unlike previous estimates, the estimates in Equation (2) do not use draft position. They instead use a normalized draft position, $\widetilde{d}_{l}$, which is centered on the transition in question (either from the lottery to non-lottery first-round picks or from the first round to the second round). As our results may vary based on whether we treat the cut point as the final pick before a transition or the first pick after that transition, we define cut points as being halfway between the picks in question and recast draft position as the distance between draft position and the cut point. ${ }^{15}$ When running local linear regressions, we restrict $\widetilde{d}_{l}$ to lie within a bandwidth $h$, such that $-h \leq \widetilde{d}_{\imath} \leq h$, where $h$ is allowed to vary across specifications.

\footnotetext{
${ }^{14}$ The threshold for the first round was 29 draft picks from 1995 to 2004, when it rose to 30 with the admission of the Charlotte Bobcats.

${ }^{15}$ Thus, in 2005 the cut point associated with lottery status would be located at 16.5. The last lottery pick would be assigned a value of -0.5 , the previous pick would be assigned a value of -1.5 , and so on. The first non-lottery pick would be assigned a value of 0.5 , the next pick would be assigned a value of 1.5 , and so on.
} 
We estimate two separate equations because the distance between the last lottery pick and the last first-round pick is not the same for every year. This occurs for several reasons, including the NBA's growth from 29 to 30 teams in 2004 (when the Charlotte Bobcats entered the NBA) and the loss of draft picks by the Minnesota Timberwolves in 2001, 2002, and 2004 due to violations of the league's salary cap. Changes in the location of the two thresholds make simultaneous analysis of both discontinuities impossible, so we consider one discontinuity at a time.

Previous studies have essentially modeled playing time as a function of performance and draft position, with Staw and Hoang (1995) using a dummy variable to denote whether a player was injured in a given year. We take a more careful approach to accounting for time lost due to injuries, suspensions (e.g., for fighting or drug offenses), or other exogenous reasons. To account for such outside influences on playing time, we compute the number of games missed due to injury or suspension and use this to approximate a player's maximal number of regulation minutes in each season. We then use the ratio of the actual number of minutes played to the maximal number of minutes as our dependent variable. If a player is on the court for every possible minute of regulation time this variable would equal 1 , and it would equal 0 for a player who was on a team roster but did not play at all. In our sample, the fraction varied from 0.066 to 0.886 . We are not surprised that no player had a value of 1 , as that would mean that a player either had superhuman endurance or suffered a season-ending injury after a string of complete games. A value of 0 would mean that a player was on a team's roster but never played, also a highly unlikely occurrence.

Turning to the control variables in $Z$, players at some positions might systematically receive less playing time than others. The reason might have nothing to do with the quality of the 
player but stem from the physical demands of the position or the natural tendency of players at some positions to accumulate more fouls. We therefore include dummy variables indicating a player's primary position.

Because players with more college experience are more fully developed and can make more immediate contributions, we expect college experience to have a positive impact on playing time that decreases with professional experience, as younger entrants move toward their (often greater) potential. Because of the growing presence of international players, who frequently come to the NBA from club teams rather than from college, we use a variable that captures all pre-NBA experience at either the collegiate or club level. ${ }^{16}$ Groothuis, Hill, and Perri (2007) show that younger entrants underperform relative to their draft position in their first two seasons, then surpass older players from the same draft cohort. In effect, teams picking such players accept some short-term performance cost in hopes that greater potential will emerge.

The degree of commitment to a lottery pick or first-round choice could depend upon a variety of team-related factors. In particular, teams that have performed particularly poorly in the recent past might feel more invested in a high draft choice. We include a team's lagged winning percentage and an indicator of whether it had qualified for the playoffs after the preceding season to control for team performance.

It is also possible that a variant of the principal agent problem could affect playing time. Personnel decisions, including draft selection and player transactions, are typically made by the team's upper-level management, with the general manager usually playing a leading role. Gametime decisions on playing time, however, are made by the team's coach. Because a coach's

\footnotetext{
${ }^{16}$ Adding a separate college experience variable had no impact, nor did adding a dummy variable that equaled one if the player had any college experience. Neither variable is shown in the results that follow.
} 
employment depends on the team's performance, he is more likely to respond to a player's performance than to a sense of commitment. We therefore include a dummy variable that indicates whether a team's coach is also its general manager. We expect such teams to be more affected by commitment effects than others. Only about six percent of our sample of playerseasons involves coaches with a dual role, so it might be difficult to separate differences in commitment effects from personal idiosyncrasies.

We run several sets of regressions to capture different possible manifestations of the commitment effect. We first split the data into five subsets, each of which corresponds to the number of years a player has been in the NBA. If draft position reflects teams' expectations rather than a commitment effect, we would expect the impact of being a first-round draft pick or a lottery pick to decrease over time.

We capture the impact of race on a team's commitment to its players in two ways. We first include dummy variables for race and for whether a player is foreign-born in the above equations. ${ }^{17}$ If discrimination based on race or nationality worsens a team's treatment of its players, the dummy variables should have a negative impact on playing time. We also test for the impact of race by running a separate set of regressions for all black players. (Similar regressions for white and foreign-born players are not shown here because of small sample size.)

\section{Data}

\footnotetext{
${ }^{17}$ A player is foreign if he was neither born nor raised in North America and did not attend college in the United States. Hence Canadian players such as Steve Nash are not classified as foreign. Players were classified as black based on photographic evidence found online.
} 
Our data set includes all 409 players who were drafted by NBA teams between 1995 and 2005, ever signed an NBA contract, and played at least 500 minutes in at least one season. ${ }^{18}$ It contains performance data for the first five years of the players' careers. These data represent the first eleven draft classes subject to league-mandated first round rookie contracts. The previous studies analyzed periods during which teams negotiated contract terms that preceded the scale. The predetermined salary precludes the possibility that the negotiation between a particular team and player could itself become a source of commitment. The standardized contract length also eliminates another source of heterogeneity among first-round draft choices. Players who did not make an NBA roster during the relevant time period were treated as missing. Transaction data on contract signings come from the Pro Basketball Transactions (PST) website. Performance data come from the Basketball-Reference.com website. Data on games for which a player is unavailable due to injuries, illness, suspensions, family matters, or other reasons also come from the $P S T$ website. ${ }^{19}$

Before presenting our results, we must test whether our data can yield valid estimates. The three most important qualifications in our context are 1) that player characteristics trend smoothly through the cutoff for treatment, 2) that there are no simultaneous or confounding treatments, and 3) that players near the cutoff are randomly assigned to treatment. Imbens and Lemieux (2008) and Lee (2008) formalize the first two conditions, while McCrary (2008) does so for the third.

In our context, the first condition means that player characteristics should show no discrete jumps between the last lottery and first non-lottery picks and between the final selection

\footnotetext{
${ }^{18} 107$ draftees either never signed or had missing data in at least one of their first five seasons, while another 122 failed to reach 500 minutes in any of their first five seasons.

${ }^{19}$ See http://www.basketball-reference.com and http://www.prosportstransactions.com/basketball.
} 
in the first round and the first selection in the second round. Unfortunately, the characteristics most relevant on draft day - those for high school, college, or European club performance - are difficult to obtain or were generated by varying processes and are hence not readily comparable for players who enter the NBA from different sources, or not measurable (e.g., "maturity" or "leadership").

We can test one key post-draft variable, our measure of player performance, wins produced per 48 minutes. Tests for whether WP48 is continuous across the lottery and draft rounds appear in Tables III and IV. We show the results for three bandwidths. Results for three others are available on request. The key coefficient here is for the dummy variable indicating a switch from one regime to another (lottery/non-lottery or first round/second round). This coefficient is not significant in any bandwidth, showing that performance moves smoothly across regimes. Figures 3 and 4 illustrate the continuity of performance across these thresholds for a bandwidth of 10. (Graphs for other bandwidths show similar results.) Neither figure shows a large drop in performance as one crosses the threshold from one regime to the other.

Another potential concern is whether sample sizes are balanced on either side of the cutoff for treatment. Differences in the number of observations on opposite sides of the threshold could reflect composition bias, which would raise concerns about the validity or interpretation of our findings. We test for such a difference using a McCrary density test. We perform the test using bandwidths ranging from 5 to 10 draft picks on either side of the cutoff. ${ }^{20}$

The results of this test for the lottery and for the two draft rounds appear in Table V. For each of the bandwidths shown, the coefficient on lottery status remains statistically insignificant.

\footnotetext{
${ }^{20}$ Results for other bandwidths were consistent with those shown and are available from the authors on request. For more on the McCrary density test, see McCrary (2008) and Lee and Lemieux (2010).
} 
Hence, composition bias does not pose a problem in the case of lottery picks. However, there is a noticeable drop in sample size as draft position enters the second round. The positive impact of being selected in the first round shows that players chosen in the second round of the NBA draft are far less likely to be found on team rosters than are players chosen in the first round. This finding raises the possibility of composition bias. If few second-round picks make a team's roster, then those who do make a team might be substantially more talented than those who do not, and may therefore be unrepresentative of second-round picks as a whole.

Several factors reduce our concern over this finding. First, our finding that WP48 shows no discontinuity across draft rounds means that players in our data on either side of the threshold are roughly comparable, even if first and second-round picks in general are not. Second, we are not concerned with a "typical" second-round draft choice - data by definition does not exist for unsigned players, and attempting to apply our results to them would not have any meaningful interpretation. Finally, the focus of this paper is on the treatment of players who make it onto team rosters and who register enough playing time to be part of our sample. The fact that we observe second-round draft choices who are better than the average second-round choice is therefore irrelevant for this study.

Finally, the selection of players around the cutoff into treatment must be effectively random. It is possible (and logical) that coaches seriously consider tradeoffs between the mean and variance of players' expected productivity at the cutoff between the first and second rounds - players with high variability in their expected performance should not receive a guaranteed contract over players with lower but more stable expectations. Ex ante expectations, however, should affect whether players receive a contract - and therefore appear in our data rather than the number of minutes that they play. While individual general managers select 
players in individual years based on other observable characteristics and on team needs, it is unlikely that these decisions would result in large systematic trends in treatment when pooled over many drafts.

V. Results

a. Determinants by Years of Experience

Tables VI and VII show the determinants of playing time with the data set broken down by the number of years of experience, from a player's first year in the NBA to his fifth. Table VI tests for discontinuity associated with being a lottery pick, while Table VII shows the impact of being a first-round draft choice. Figures 5-8 illustrate the fitted curves for the local linear regressions for lottery picks first-round draft picks in their first and fifth years, using bandwidths of 10 draft picks. Regressions using higher-order terms for draft order are not shown here, as the coefficients on the higher-order terms were consistently statistically insignificant. Table VIII shows a sample of a complete set of results for players with three years of experience, estimated over a bandwidth of $10 .{ }^{21}$ These results show that the additional covariates greatly improve the fit of the regression — much of it from adding our performance measure, WP48. This variable had the only coefficient that was consistently statistically significant. A player's position often had a statistically significant impact on playing time, but no one position coefficient was significant across all specifications. ${ }^{22}$ Surprisingly, black players received more playing time than white or Asian players, holding performance constant in most of the draft round equations.

\footnotetext{
${ }^{21}$ A complete set of results for each of players' first five years in the league and bandwidths from five to ten draft picks is available upon request.

${ }^{22}$ Results for centers were always negative, conditional on being statistically significant. Results for other positions varied in both sign and magnitude based on bandwidth, year, and cut point.
} 
Tables VI and VII show that there is no evidence in support of a commitment effect. Lottery picks and first-round draft choices receive no more playing time just because of their draft status. The coefficients on the respective dummy variables were seldom significant. The few significant coefficients were uniformly negative, indicating that being a lottery or first-round pick negatively affects playing time. This unexpected effect could be the result of a small sample size, which allows a few unexpectedly poor high draft picks or a few unexpectedly good low draft picks to affect the results.

\section{b. Determinants by Race}

Tables IX and X show the full results of RD estimates for lottery versus non-lottery picks and for first versus second-round draft choices with a bandwidth of 10 for Black players. Nonlinearities are much more of a factor here than they were for years of experience, as higherorder terms of draft position are consistently significant in the cubic equations. The results also show that the covariates add greatly to the quality of fit of the regressions. Thus, we focus on those regressions.

Some variables have consistently significant coefficients. For example, positions affect the playing time of black players, as players at the more "physical" positions play less than point guards (our default position). The coefficient on the dummy variable for centers is consistently negative in both the lottery and draft round equations. The coefficient for power forwards is also negative in the lottery equations. Moving to a new team also results in less playing time, suggesting that moves do not necessarily result in a better match between players and teams, or at least that there is a substantial learning curve for newly-acquired players. All else equal, playing time increases with experience, as the dummy variables for years 2 through 5 are 
consistently positive in the lottery equation and years 3 through 5 are positive in the draft-round equation. By far the strongest impact was made by our performance measure. Wins produced per 48 minutes had a coefficient of about 0.8 in the lottery equation and of over 0.9 in the draftround equation.

A few variables had coefficients that were significant only in certain equations. Most notably, foreign players had consistently more playing time in the draft-round equation but were indistinguishable from native-born players in the lottery equation. A team's lagged winning percentage had a negative impact playing time in the cubic version of the lottery equation. Playing for a coach who was also the general manager had a positive impact in the linear version of the draft-round equation.

The dummy variables showed little evidence of a commitment effect. Only the coefficient in the expanded linear version of the lottery equation was statistically significant, which indicates that lottery picks had less playing time, all else equal. The other coefficients in the lottery equations were statistically insignificant.

Several variables in the draft-round equations were statistically significant. The linear and cubic terms in expanded versions of the equation indicated that first-round picks had less playing time, all else equal. This may reflect that second-round players who accumulate any playing time are a somewhat selected sample, as indicated above, and may have better unobservable characteristics than corresponding first-round players. 
VI. Conclusions and Further Research

We find no evidence that NBA teams exhibit discontinuous commitment to players whom they draft in the first round or in the lottery over those drafted later. Our RD results show that players drafted in the above positions receive no more playing time - and, in some situations, receive less playing time - than other players. This finding contradicts the conclusions of Staw and Hoang's seminal paper. It also moves farther along the path suggested by Camerer and Weber who found a small commitment effect.

We see three possible reasons why our findings differ. First, the two previous studies use relatively simple global models, in which draft position appears linearly. As Angrist and Pischke (2008) point out, global linear specifications can lead to the mistaken conclusion that a discontinuity exists. Using a more sophisticated RD framework causes such spurious discontinuities to disappear.

Second, we use a broader and more commonly accepted measure of performance - wins produced per 48 minutes - than do the other studies. Since performance is the single most important determinant of playing time, correctly specifying performance is vital for any study of playing time. Finally, we more precisely account for playing time that is lost to outside factors such as injury. Our dependent variable, the ratio of a player's actual playing time to his maximum possible playing time, more accurately captures the team's use of the player.

While our main focus is on the possible discontinuity associated with lottery picks or firstround draft choices, we also find no clear general effect of draft position on playing time when controlling for performance. The coefficient on normalized draft order is significant in only about half the specifications. This contrasts with the impact of our performance measure, which has a strong, positive impact in all specifications. 
Our findings thus show that teams clearly prize performance over draft order. This suggests, in turn, that neoclassical theory explains NBA teams' behavior better than behavioral theory does. To the extent that the NBA serves as a laboratory in which superior data allow us to draw conclusions about "real world" behavior, we may make a similar inference about firm behavior in general.

Sources

"2013-14 NBA Rookie Salary Scale," Hoopsworld, at http://www.hoopsworld.com/2013-14rookie-salary-scale/, viewed October 6, 2013.

Angrist, Joshua D. and Jorn-Steffen Pischke. 2008. Mostly Harmless Econometrics, Princeton, Princeton University Press.

Basketball-Reference website. http://www.basketball-reference.com. Accessed many times, 2008-12.

Berri, David J. (2008), "A Simple Model of Worker Productivity in the National Basketball Association”. In The Business of Sports, edited by Brad R. Humphreys and Dennis R. Howard, Praeger: Westport, CT. pp. 1-40.

Berri, David, Stacey Brook, Aju Fenn, Bernd Frick, and Roberto Vincente-Mayoral. 2005. "The Short Supply of Tall People: Explaining Competitive Imbalance in The National Basketball Association," Journal of Economic Issues, 39(4), December: 1020-2041.

Berri, David J., and Martin B. Schmidt. 2002. "Instrumental versus Bounded Rationality: A Comparison of Major League Baseball and the National Basketball Association”, Journal of Socio-Economics 31: 191-214.

Berri, David J.; Martin B. Schmidt, and Stacey. L. Brook. 2004. "Stars at the Gate: The Impact of Star Power on NBA Gate Revenues", Journal of Sports Economics 5 (Feb, no. 1). 33-50.

Berri, David, Martin Schmidt, and Stacey Brook. 2006. The Wages of Wins, Palo Alto: Stanford University Press.

Bodvarsson, Orn B. and Raymond D. Brastow. 1999. "A Test of Employer Discrimination in the NBA," Contemporary Economic Policy, 17(2), April: 243-255. 
Camerer, Colin F. and Roberto A. Weber. 1999. "The Econometrics and Behavioral Economics of the Escalation of Commitment: A Re-examination of Staw and Hoang's NBA Data," Journal of Economic Behavior and Organization, 39(1), May: 59-82.

DiNardo, John and David S. Lee. 2004. "Economic Impacts of New Union Unionization on Private Sector Employers: 1984-2001," Quarterly Journal of Economics, 119(4), November: 1383-1441.

Groothuis, Peter A.; James Richard Hill; and Timothy J. Perri. 2007. "Early Entry in the NBA Draft: The Influence of Unraveling, Human Capital, and Option Value." Journal of Sports Economics 8(3), June: 223-243.

Hamilton, Barton H. 1997. "Racial Discrimination and Professional Basketball Salaries in the 1990s,” Applied Economics, 29(3), March: 287-296.

Imbens, Guido W. and Thomas Lemieux. 2008. "Regression discontinuity designs: A guide to practice," Journal of Econometrics 142(2), 615-635.

Kahn, Lawrence M. and Peter D. Sherer. 1988. "Racial Differences in Professional Basketball Players' Compensation,” Journal of Labor Economics, 6(1), January: 40-61.

Kanazawa, Mark T. and Jonas P. Funk. 2001. "Racial Discrimination in Professional Basketball: Evidence from Nielsen Ratings," Economic Inquiry, 39(4), October: 599-608.

Khan, Bashir A., Salter, Stephen B., and Sharp, David J. 2000. "Throwing Good Money After Bad: A Comparison of Asian and Developed Country Managerial Decision-Making in Sunk Cost Situations," Asian Pacific Development Journal 7, 105-120.

Krautmann, Anthony, Peter von Allmen, and David J. Berri. 2009. "Underpayment of Restricted Players in North American Sports Leagues", International Journal of Sport Finance 4, 161 75.

Lee, David S. 2008. "Randomized Experiments from Non-random Selection in U.S. House Elections," Journal of Econometrics, 142(2), February: 675-697.

McAfee, R. Preston, Hugo M. Mialon, and Sue H. Mialon. 2010. "Do Sunk Costs Matter?" Economic Inquiry, 48(2), April:323-336.

McCrary, Justin. 2008 "Manipulation of the running variable in the regression discontinuity design: A density test," Journal of Econometrics, 142(2), 698-714

Motomura, Akira. 2011. "MoneyRoundball? The Drafting of International Players by National Basketball Association Teams" Working Paper. 
Price, Joseph, Brian P. Soebbing, David J. Berri; and Brad R. Humphreys. 2010. “Tournament Incentives, League Policy, and NBA Team Performance Revisited"; Journal of Sports Economics 11(2), April: 117-35.

Pro Sports Transactions website. 2005-2011. http://www.prosportstransactions.com/basketball/. Viewed many times 2008-2012.

Rosenbaum, Dan T., (2003) "It Doesn't Pay to be Young in the NBA" University of North Carolina at Greensboro working paper September 2003. Downloaded August 1, 2008 from www.uncg.edu/bae/people/rosenbaum/youngnba1.pdf (page since taken down).

Soebbig, Brian P. and Daniel S. Mason. 2009. "Managing Legitimacy and Uncertainty in Professional Team Sport: The NBA's Draft Lottery," Managing Team Performance, 15(3/4): 141-157.

Staw, Barry M. and Ha Hoang. 1995. "Sunk Costs in the NBA: Why Draft Order Affects Playing Time in Professional Basketball," Administrative Science Quarterly 40: 474-494.

Taylor, Beck A. and Justin G. Trogdon. 2002. "Losing to Win: Tournament Incentives in the National Basketball Association," Journal of Labor Economics, v. 20, no. 1, January: 23-41.

Thaler, Richard. 1980. "Towards a Positive Theory of Consumer Choice," Journal of Economic Behavior and Organization, v. 1: 39-60.

Tversky, Amos and Daniel Kahneman. 1981. "The Framing of Decisions and the Psychology of Choice,” Science, v. 211, no. 4481, January 30: 453-458. 
Sunk Costs and the NBA, November 2013, p. 26

Figure 1

Playing Time As a Linear Step-function

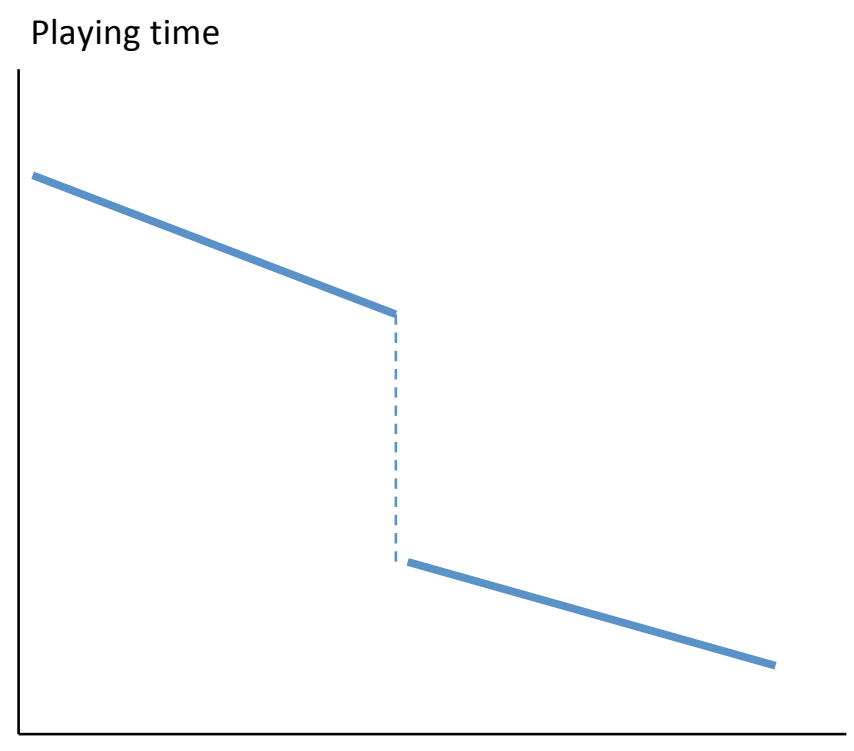

Draft Position 
Sunk Costs and the NBA, November 2013, p. 27

Figure 2

Playing Time as a Continuous, Nonlinear Function

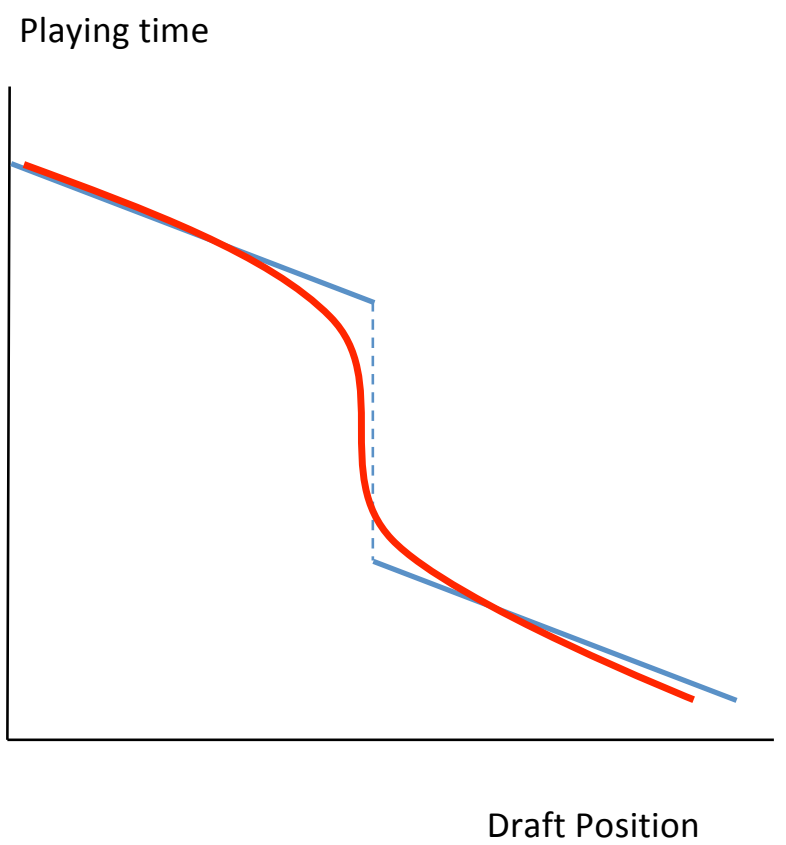


Figure 3 - Continuity Test of Performance Measure across the Lottery Threshold

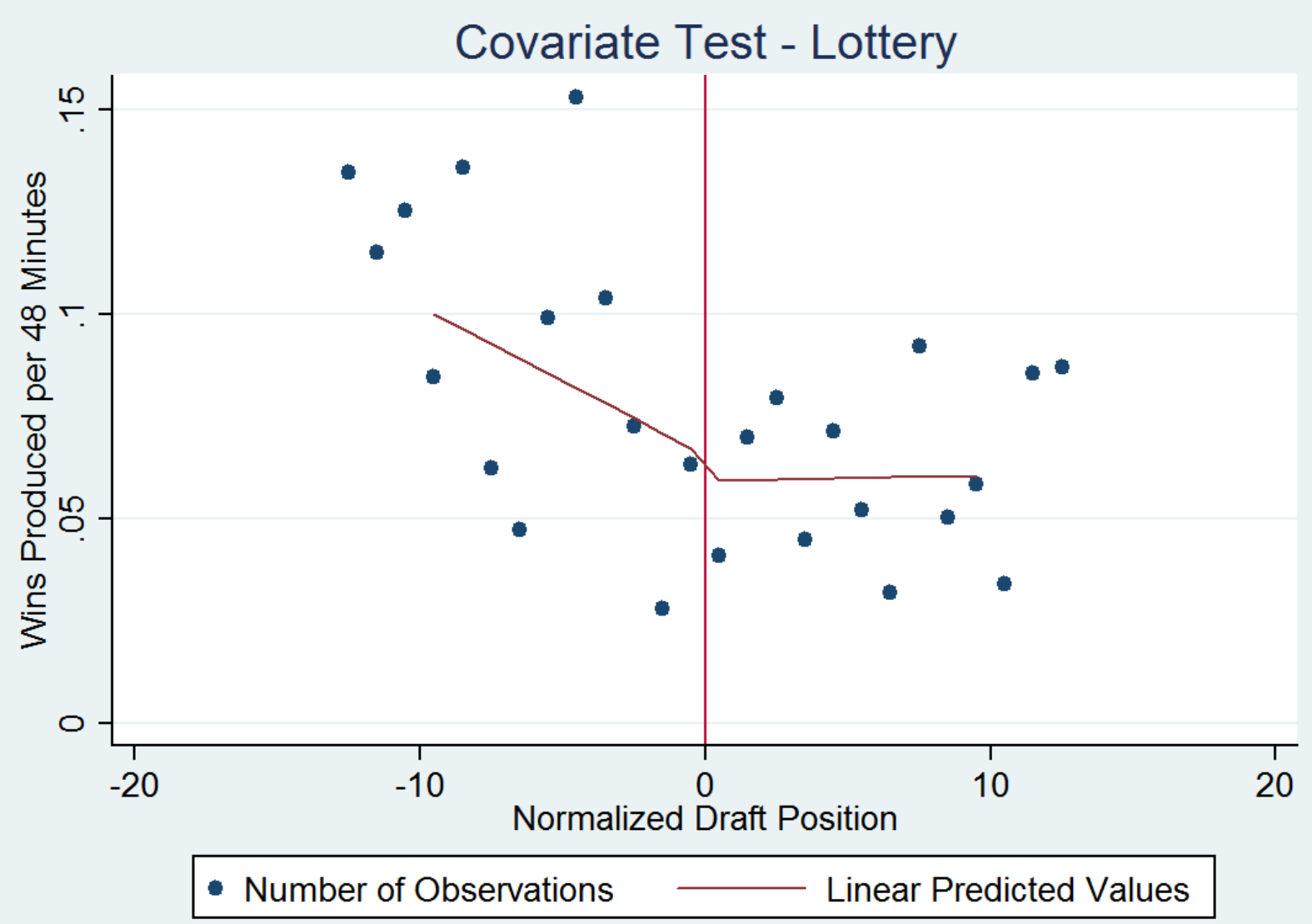


Sunk Costs and the NBA, November 2013, p. 29

Figure 4-Continuity Test of Performance Measure across the First-Round Threshold

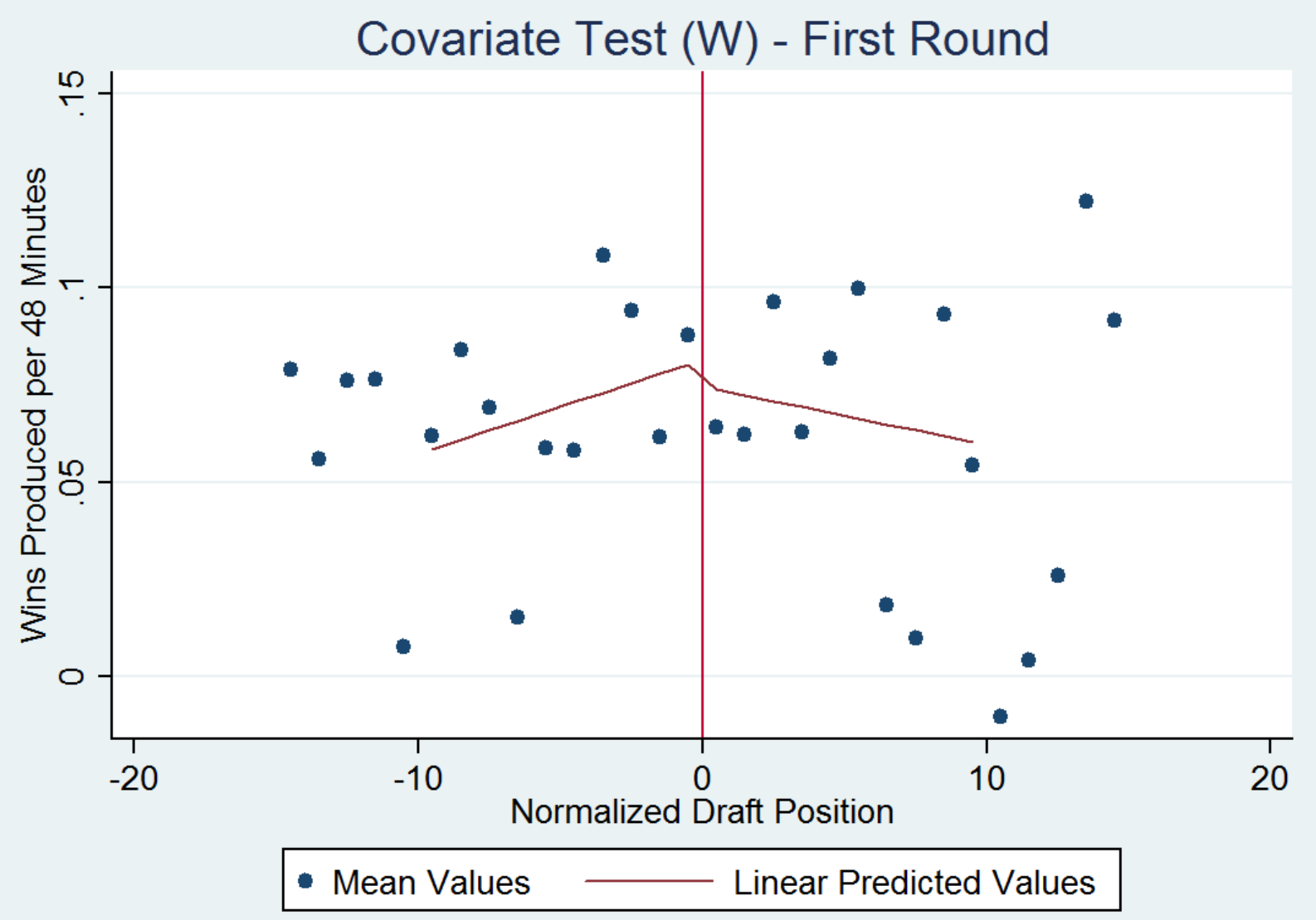




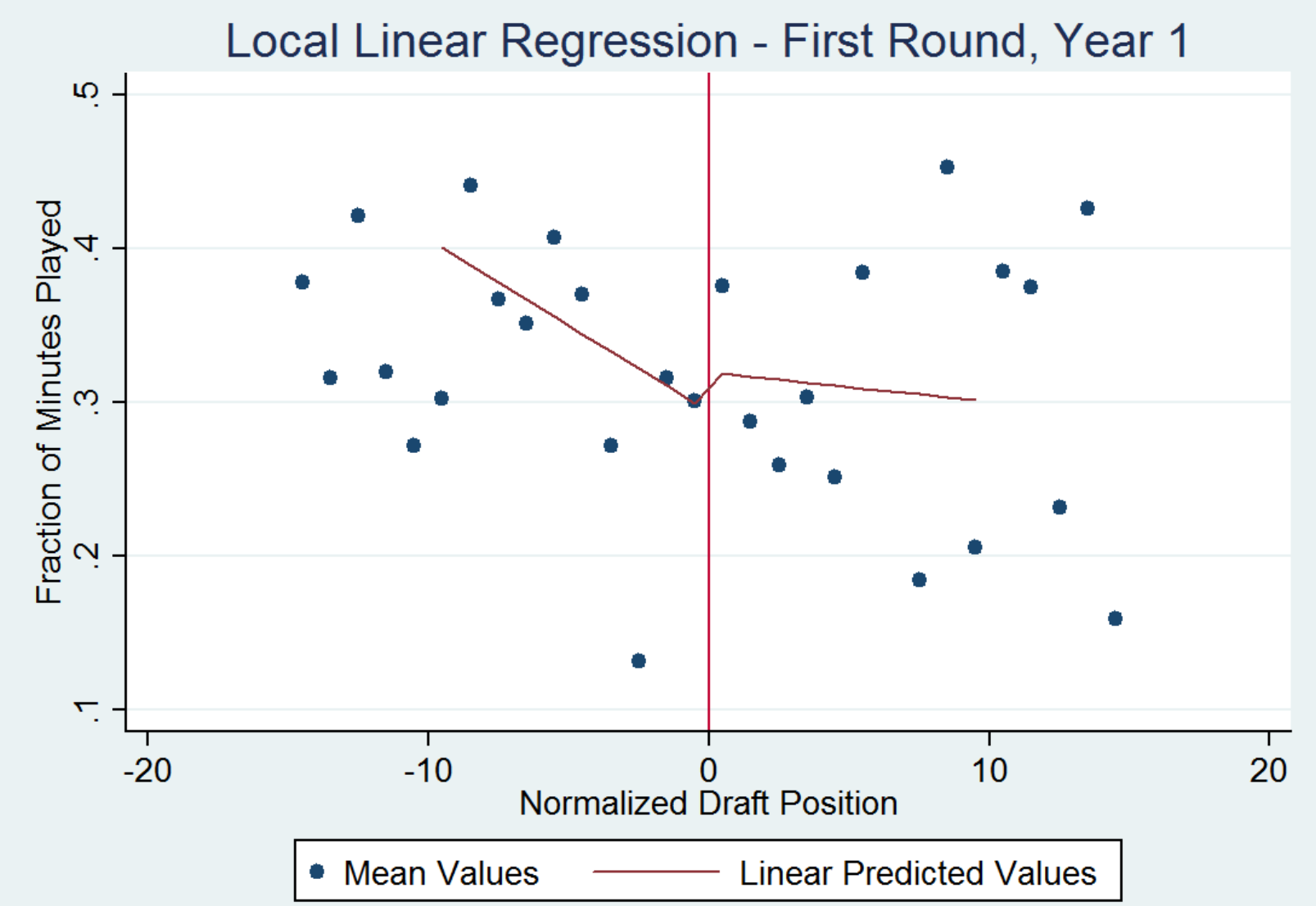

Figure 5 
Sunk Costs and the NBA, November 2013, p. 31

Figure 6

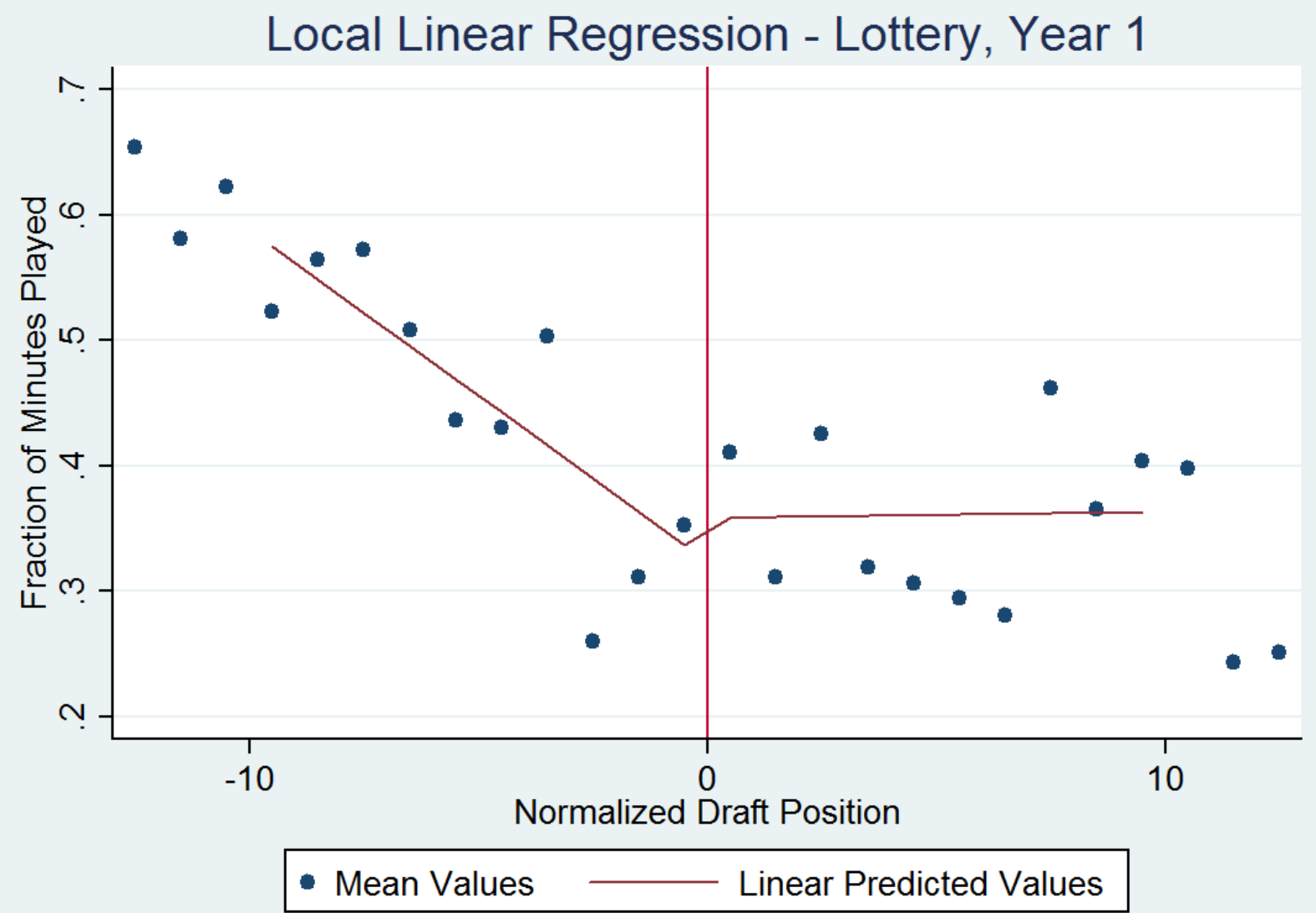




\section{Figure 7}

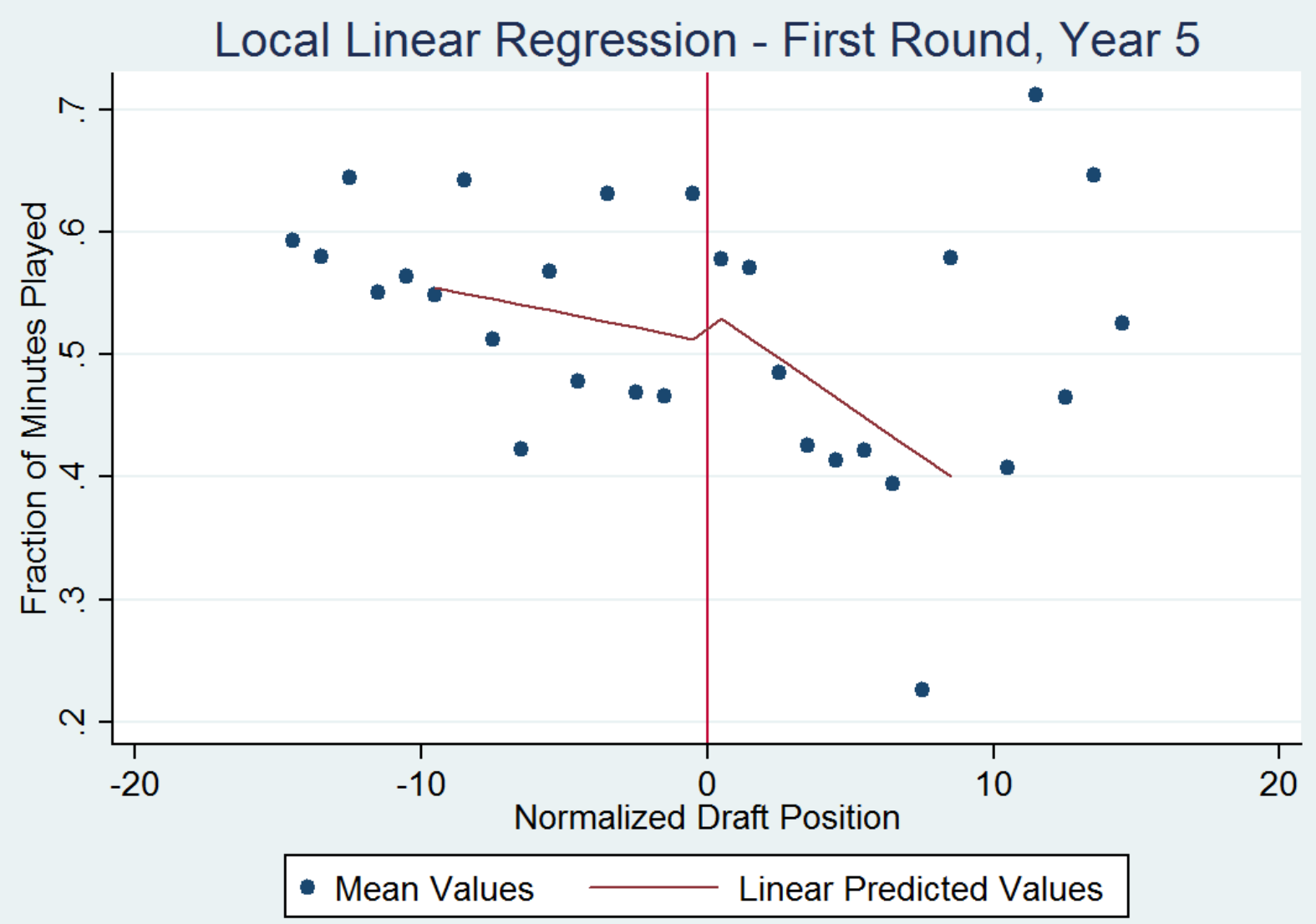


Sunk Costs and the NBA, November 2013, p. 33

Figure 8

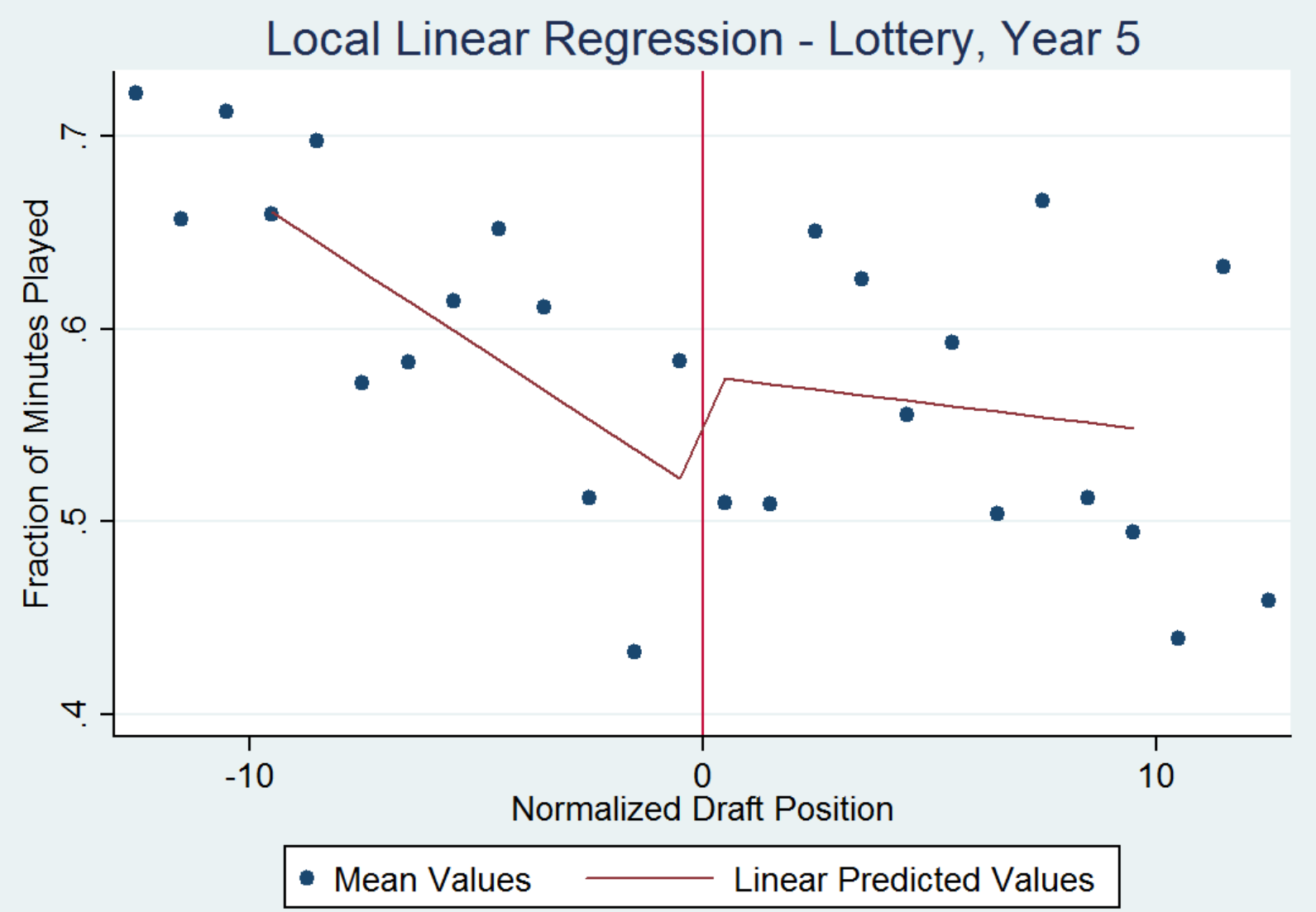


Sunk Costs and the NBA, November 2013, p. 34

Table I: Number of Non-zero Observations

\begin{tabular}{l|l} 
Draft status & Number of Player-seasons
\end{tabular}

\begin{tabular}{|l|l|}
\hline Second round pick & 643 \\
\hline
\end{tabular}

Non-lottery first round pick

Lottery pick

698

721 
Sunk Costs and the NBA, November 2013, p. 35

\begin{tabular}{|l|c|c|c|}
\hline \multicolumn{4}{|c|}{ Table II: Mean Minutes played and Efficiency by Draft Status } \\
\hline \multicolumn{1}{|c|}{ Variable } & $\begin{array}{c}\text { Unconditional } \\
\text { Mean of Minutes }\end{array}$ & $\begin{array}{c}\text { Conditional Mean } \\
\text { of Minutes }\end{array}$ & $\begin{array}{c}\text { Mean } \\
\text { Performance }\end{array}$ \\
\hline Second-round picks & 0.1270 & 0.2563 & 0.0047 \\
\hline Non-lottery first-round picks & 0.3075 & 0.3599 & 0.0560 \\
\hline Lottery picks & 0.5140 & 0.5332 & 0.0791 \\
\hline
\end{tabular}


Sunk Costs and the NBA, November 2013, p. 36

\begin{tabular}{|l|l|l|l|}
\hline \multicolumn{4}{|c|}{ Table III: Continuity of WP48 Across the Lottery } \\
\hline Variable & Bandwidth=10 & Bandwidth=8 & Bandwidth=5 \\
\hline Draft Position & 0.0001 & 0.0013 & 0.0039 \\
& $(0.08)$ & $(0.52)$ & $(0.80)$ \\
\hline Lottery Pick & 0.0062 & 0.0143 & -0.0278 \\
& $(0.47)$ & $(0.94)$ & $(1.45)$ \\
\hline Interaction Term & 0.038 & -0.0030 & $-0.0283^{* * *}$ \\
& $(1.64)$ & $(0.92)$ & $(4.23)$ \\
\hline Adjusted $\mathrm{R}^{2}$ & 0.0207 & 0.0044 & 0.0736 \\
\hline Number of Observations & 787 & 623 & 387 \\
\hline
\end{tabular}

$t$-statistics in parentheses

*Significant at the 10-percent level

**Significant at the 5-percent level

***Significant at the 1-percent level 
Sunk Costs and the NBA, November 2013, p. 37

\begin{tabular}{|l|l|l|l|}
\hline \multicolumn{4}{|c|}{ Table IV: Continuity of WP48 Across Draft Rounds } \\
\hline Variable & Bandwidth=10 & Bandwidth=8 & Bandwidth=5 \\
\hline Draft Position & -0.0015 & -0.0058 & 0.0039 \\
& $(0.57)$ & $(1.54)$ & $(0.54)$ \\
\hline Drafted in Round 1 & 0.0070 & 0.0061 & 0.0209 \\
& $(0.39)$ & $(0.30)$ & $(0.83)$ \\
\hline Interaction Term & 0.0039 & $0.0118^{* * *}$ & -0.0021 \\
& $(1.23)$ & $(2.55)$ & $(0.23)$ \\
\hline Adjusted R ${ }^{2}$ & -0.0019 & 0.0121 & -0.0103 \\
\hline Number of Observations & 456 & 354 & 225 \\
\hline
\end{tabular}

$t$-statistics in parentheses

* Significant at the 10-percent level

**Significant at the 5-percent level

***Significant at the 1-percent level 


\begin{tabular}{|l|l|l|}
\hline \multicolumn{3}{|c|}{ Table V: Impact of Threshold on Density } \\
\hline Bandwidth & Lottery & First Round \\
\hline 10 & -3.5303 & 8.8348 \\
& $(0.76)$ & $(1.87)$ \\
\hline 8 & -3.2202 & 10.6548 \\
& $(0.60)$ & $(2.45)$ \\
\hline 5 & 4.1000 & 13.9500 \\
& $(0.52)$ & $(3.66)$ \\
\hline
\end{tabular}




\begin{tabular}{|l|l|l|l|}
\hline \multicolumn{4}{|c|}{ Table VI: Linear Estimate of Discontinuity Across Lottery By Years of Experience } \\
\hline Specification & Bandwidth=10 & Bandwidth=8 & Bandwidth=5 \\
\hline Year 1 & -0.0066 & -0.0344 & -0.0856 \\
With Covariates & $(0.14)$ & $(0.60)$ & $(1.34)$ \\
\hline Year 1 & -0.0351 & -0.0633 & $-0.1027 \#$ \\
Without Covariates & $(0.69)$ & $(1.14)$ & $(1.65)$ \\
\hline Year 2 & $-0.0905^{*}$ & $-0.1115^{*}$ & -0.1208 \\
With Covariates & $(1.84)$ & $(1.92)$ & $(1.58)$ \\
\hline Year 2 & $-0.1146^{* *}$ & $-0.1332^{* *}$ & $-0.1458^{* *}$ \\
Without Covariates & $(2.14)$ & $(2.26)$ & $(2.00)$ \\
\hline Year 3 & -0.0721 & -0.0372 & -0.0527 \\
With Covariates & $(1.33)$ & $(0.59)$ & $(0.65)$ \\
\hline Year 3 & -0.0523 & -0.0251 & -0.0863 \\
Without Covariates & $(0.89)$ & $(0.37)$ & $(1.02)$ \\
\hline Year 4 & 0.0355 & 0.0260 & 0.0517 \\
With Covariates & $(0.71)$ & $(0.44)$ & $(0.70)$ \\
\hline Year 4 & 0.0626 & 0.0930 & 0.0804 \\
Without Covariates & $(1.07)$ & $(1.37)$ & $(0.88)$ \\
\hline Year 5 & -0.0583 & -0.0230 & -0.0002 \\
With Covariates & $(1.16)$ & $(0.39)$ & $(0.00)$ \\
\hline Year 5 & -0.0612 & -0.0092 & -0.0426 \\
Without Covariates & $(1.05)$ & $(0.14)$ & $(0.47)$ \\
\hline t-statistin & & \\
\hline
\end{tabular}

t-statistics in parentheses

* Significant at the 10-percent level

**Significant at the 5-percent level

***Significant at the 1-percent level

\#Not significant at the $10 \%$ level because of the small sample size $(n=71)$ 


\begin{tabular}{|l|l|l|l|}
\hline \multicolumn{3}{|c|}{ Table VII: Linear Estimate of Discontinuity Across Draft Rounds By Years of Experience } \\
\hline Specification & Bandwidth=10 & Bandwidth=8 & Bandwidth=5 \\
\hline Year 1 & 0.0708 & 0.0270 & -0.0032 \\
With Covariates & $(1.16)$ & $(0.41)$ & $(0.03)$ \\
\hline Year 1 & -0.0257 & -0.0697 & -0.0748 \\
Without Covariates & $(0.40)$ & $(1.07)$ & $(0.96)$ \\
\hline Year 2 & 0.0176 & -0.0077 & -0.0572 \\
With Covariates & $(0.30)$ & $(0.12)$ & $(0.57)$ \\
\hline Year 2 & 0.0016 & -0.0236 & -0.0182 \\
Without Covariates & $(0.02)$ & $(0.33)$ & $(0.21)$ \\
\hline Year 3 & -0.1057 & $-0.1268 \#$ & -0.1046 \\
With Covariates & $(1.56)$ & $(1.66)$ & $(1.05)$ \\
\hline Year 3 & -0.0746 & -0.1139 & -0.1614 \\
Without Covariates & $(0.99)$ & $(1.42)$ & $(1.62)$ \\
\hline Year 4 & -0.0538 & -0.0102 & -0.0684 \\
With Covariates & $(0.66)$ & $(0.11)$ & $(0.51)$ \\
\hline Year 4 & 0.0172 & -0.032 & -0.1231 \\
Without Covariates & $(0.22)$ & $(0.38)$ & $(1.14)$ \\
\hline Year 5 & -0.1009 & $-0.1635^{*}$ & -0.1308 \\
With Covariates & $(1.20)$ & $(1.78)$ & $(1.06)$ \\
\hline Year 5 & -0.0275 & -0.0592 & -0.0601 \\
Without Covariates & $(0.31)$ & $(0.62)$ & $(0.50)$ \\
\hline
\end{tabular}

t-statistics in parentheses

* Significant at the 10-percent level

**Significant at the 5-percent level

***Significant at the 1-percent level

\#Not significant at the $10-\%$ level because of the small sample size $(n=77)$ 


\begin{tabular}{|c|c|c|c|c|}
\hline \multicolumn{5}{|c|}{ Table VIII: Full Set of Regressors for Three Years of Experience and Bandwidth=10 } \\
\hline Variable & Lottery -1 & Lottery - 2 & Draft Round -1 & Draft Round - 2 \\
\hline $\begin{array}{l}\text { Normed Draft } \\
\text { Position }\end{array}$ & $\begin{array}{l}-0.0088 \\
(1.14) \\
\end{array}$ & $\begin{array}{l}-0.0124^{*} \\
(1.72) \\
\end{array}$ & $\begin{array}{l}-0.0052 \\
(0.47) \\
\end{array}$ & $\begin{array}{l}-0.0038 \\
(0.40) \\
\end{array}$ \\
\hline Lottery Pick & $\begin{array}{l}-0.0523 \\
(0.89) \\
\end{array}$ & $\begin{array}{l}-0.0721 \\
(1.33) \\
\end{array}$ & & \\
\hline $\begin{array}{l}\text { Drafted in First } \\
\text { Round }\end{array}$ & & & $\begin{array}{l}-0.0746 \\
(0.99)\end{array}$ & $\begin{array}{l}-0.1057 \\
(1.56)\end{array}$ \\
\hline Interaction Term & $\begin{array}{l}-0.0110 \\
(1.08) \\
\end{array}$ & $\begin{array}{l}-0.0040 \\
(0.42) \\
\end{array}$ & $\begin{array}{l}-0.0104 \\
(0.77) \\
\end{array}$ & $\begin{array}{l}-0.0148 \\
(1.30) \\
\end{array}$ \\
\hline Shooting Guard & & $\begin{array}{l}-0.031 \\
(0.68) \\
\end{array}$ & & $\begin{array}{l}-0.0276 \\
(0.56) \\
\end{array}$ \\
\hline Small Forward & & $\begin{array}{l}0.0054 \\
(0.11)\end{array}$ & & $\begin{array}{l}0.0975^{*} \\
(1.72)\end{array}$ \\
\hline Power Forward & & $\begin{array}{l}-0.1052^{* *} \\
(2.18) \\
\end{array}$ & & $\begin{array}{l}0.0180 \\
(0.39) \\
\end{array}$ \\
\hline Center & & $\begin{array}{l}-0.1332 * * * \\
(2.70)\end{array}$ & & $\begin{array}{l}-0.0463 \\
(0.97) \\
\end{array}$ \\
\hline $\begin{array}{l}\text { Wins Produced } \\
\text { per } 48 \text { Minutes }\end{array}$ & & $\begin{array}{l}0.6686^{* * * *} \\
(4.14) \\
\end{array}$ & & $\begin{array}{l}1.1643^{* * *} \\
(6.38)\end{array}$ \\
\hline $\begin{array}{l}\text { Lagged Winning } \\
\text { Percentage }\end{array}$ & & $\begin{array}{l}0.047 \\
(0.32) \\
\end{array}$ & & $\begin{array}{l}0.1033 \\
(0.57) \\
\end{array}$ \\
\hline $\begin{array}{l}\text { Made Playoffs in } \\
\text { Previous Year }\end{array}$ & & $\begin{array}{l}-0.0056 \\
(0.14)\end{array}$ & & $\begin{array}{l}-0.0422 \\
(0.84)\end{array}$ \\
\hline Changed Teams & & $\begin{array}{l}-0.0607 \\
(2.07) \\
\end{array}$ & & $\begin{array}{l}-0.0414 \\
(1.13) \\
\end{array}$ \\
\hline Black Player & & $\begin{array}{l}0.0093 \\
(0.25) \\
\end{array}$ & & $\begin{array}{l}0.0686^{*} \\
(1.80) \\
\end{array}$ \\
\hline $\begin{array}{l}\text { Foreign-born } \\
\text { Player }\end{array}$ & & $\begin{array}{l}-0.0245 \\
(0.41) \\
\end{array}$ & & $\begin{array}{l}0.0478 \\
(0.66) \\
\end{array}$ \\
\hline $\begin{array}{l}\text { Years of College } \\
\text { Completed }\end{array}$ & & $\begin{array}{l}0.0076 \\
(0.67) \\
\end{array}$ & & $\begin{array}{l}-0.0111 \\
(0.79) \\
\end{array}$ \\
\hline $\begin{array}{l}\text { Coach Was Also } \\
\text { General Manager }\end{array}$ & & $\begin{array}{l}0.0654 \\
(1.12)\end{array}$ & & $\begin{array}{l}0.1055 \\
(1.55) \\
\end{array}$ \\
\hline Constant & $\begin{array}{l}0.5195 \\
(12.11) \\
\end{array}$ & $\begin{array}{l}0.5252 \\
(5.69) \\
\end{array}$ & $\begin{array}{l}0.4347 * * * \\
(7.17) \\
\end{array}$ & $\begin{array}{l}0.2945^{* * *} \\
(2.63) \\
\end{array}$ \\
\hline Adjusted $R^{2}$ & 0.0908 & 0.2521 & 0.0187 & 0.3820 \\
\hline Observations & 168 & 168 & 98 & 98 \\
\hline
\end{tabular}

$t$-statistics in parentheses

* Significant at the 10-percent level

**Significant at the 5-percent level

***Significant at the 1-percent level 
Sunk Costs and the NBA, November 2013, p. 42

\begin{tabular}{|c|c|c|c|c|}
\hline \multicolumn{5}{|c|}{ Lottery-Black Players Only } \\
\hline Variable & Linear -1 & Linear -2 & Cubic - 1 & Cubic -2 \\
\hline $\begin{array}{l}\text { Normalized } \\
\text { Draft Order }\end{array}$ & $\begin{array}{l}-0.0019 \\
(0.47)\end{array}$ & $\begin{array}{l}-0.0041 \\
(1.18)\end{array}$ & $\begin{array}{l}-0.0102 \\
(0.24)\end{array}$ & $\begin{array}{l}-0.0717^{*} \\
(1.94)\end{array}$ \\
\hline $\begin{array}{l}\text { Normalized } \\
\text { Order }^{2}\end{array}$ & & & $\begin{array}{l}0.0036 \\
(0.36)\end{array}$ & $\begin{array}{l}0.0173^{* *} \\
(2.03)\end{array}$ \\
\hline $\begin{array}{l}\text { Normalized } \\
\text { Order }^{3}\end{array}$ & & & $\begin{array}{l}-0.0003 \\
(0.47)\end{array}$ & $\begin{array}{l}-0.0012^{* *} \\
(2.10)\end{array}$ \\
\hline Lottery Pick & $\begin{array}{l}-0.0342 \\
(1.08)\end{array}$ & $\begin{array}{l}-0.0505^{*} \\
(1.85)\end{array}$ & $\begin{array}{l}-0.0217 \\
(0.34)\end{array}$ & $\begin{array}{l}-0.0761 \\
(1.41)\end{array}$ \\
\hline $\begin{array}{l}\text { Interaction of } \\
\text { Linear Terms }\end{array}$ & $\begin{array}{l}-0.0162^{* * *} \\
(3.08)\end{array}$ & $\begin{array}{l}-0.0116^{* *} \\
(2.56)\end{array}$ & $\begin{array}{l}0.0020 \\
(0.04)\end{array}$ & $\begin{array}{l}-0.0826^{*} \\
(1.71)\end{array}$ \\
\hline $\begin{array}{l}\text { Interaction of } \\
\text { Quadratics }\end{array}$ & & & $\begin{array}{l}-0.0015 \\
(0.12)\end{array}$ & $\begin{array}{l}-0.0121 \\
(1.09)\end{array}$ \\
\hline $\begin{array}{l}\text { Interaction of } \\
\text { Cubics }\end{array}$ & & & $\begin{array}{l}0.0004 \\
(0.50)\end{array}$ & $\begin{array}{l}0.0014^{*} \\
(1.96)\end{array}$ \\
\hline $\begin{array}{l}\text { Shooting } \\
\text { Guard }\end{array}$ & & $\begin{array}{l}0.0321 \\
(1.64)\end{array}$ & & $\begin{array}{l}0.0261 \\
(1.30)\end{array}$ \\
\hline $\begin{array}{l}\text { Small } \\
\text { Forward }\end{array}$ & & $\begin{array}{l}0.0313 \\
(1.53)\end{array}$ & & $\begin{array}{l}0.0306 \\
(1.50)\end{array}$ \\
\hline $\begin{array}{l}\text { Power } \\
\text { Forward }\end{array}$ & & $\begin{array}{l}-0.0465^{* *} \\
(2.16)\end{array}$ & & $\begin{array}{l}-0.0517^{* *} \\
(2.40)\end{array}$ \\
\hline Center & & $\begin{array}{l}-0.0828 * * * \\
(3.60)\end{array}$ & & $\begin{array}{l}-0.0852^{* * *} \\
(3.69)\end{array}$ \\
\hline $\begin{array}{l}\text { Win Produced } \\
\text { per } 48 \text { Mins }\end{array}$ & & $\begin{array}{l}0.7964 * * * \\
(10.87)\end{array}$ & & $\begin{array}{l}0.8127^{* * *} \\
(11.01)\end{array}$ \\
\hline $\begin{array}{l}\text { Lagged } \\
\text { Winning Pct }\end{array}$ & & $\begin{array}{l}-0.1133 \\
(1.63)\end{array}$ & & $\begin{array}{l}-0.1151^{*} \\
(1.66)\end{array}$ \\
\hline $\begin{array}{l}\text { Playoffs in } \\
\text { Previous Year }\end{array}$ & & $\begin{array}{l}-0.0177 \\
(0.88)\end{array}$ & & $\begin{array}{l}-0.0158 \\
(0.78)\end{array}$ \\
\hline $\begin{array}{l}\text { Playing for } \\
\text { New Team }\end{array}$ & & $\begin{array}{l}-0.0532^{* * *} \\
(3.37)\end{array}$ & & $\begin{array}{l}-0.0538^{* * *} \\
(3.40)\end{array}$ \\
\hline $\begin{array}{l}\text { Foreign } \\
\text { Player }\end{array}$ & & $\begin{array}{l}0.0022 \\
(0.06)\end{array}$ & & $\begin{array}{l}-0.0050 \\
(0.14)\end{array}$ \\
\hline $\begin{array}{l}\text { Years of } \\
\text { College }\end{array}$ & & $\begin{array}{l}0.0071 \\
(1.43)\end{array}$ & & $\begin{array}{l}0.0063 \\
(1.27)\end{array}$ \\
\hline $\begin{array}{l}\text { Coach and } \\
\text { GM }\end{array}$ & & $\begin{array}{l}-0.0092 \\
(0.37)\end{array}$ & & $\begin{array}{l}-0.0136 \\
(0.54)\end{array}$ \\
\hline $\begin{array}{l}\text { Second Year } \\
\text { in NBA }\end{array}$ & & $\begin{array}{l}0.0451^{* *} \\
(2.21)\end{array}$ & & $\begin{array}{l}0.0447^{* *} \\
(2.19)\end{array}$ \\
\hline $\begin{array}{l}\text { Third Year in } \\
\text { NBA }\end{array}$ & & $\begin{array}{l}0.0977^{* * *} \\
(4.57)\end{array}$ & & $\begin{array}{l}0.0982^{* * *} \\
(4.60)\end{array}$ \\
\hline $\begin{array}{l}\text { Fourth Year in } \\
\text { NBA }\end{array}$ & & $\begin{array}{l}0.1258^{* * *} \\
(5.56)\end{array}$ & & $\begin{array}{l}0.1254^{* * *} \\
(5.55)\end{array}$ \\
\hline
\end{tabular}


Sunk Costs and the NBA, November 2013, p. 43

\begin{tabular}{|l|l|l|l|l|}
\hline $\begin{array}{l}\text { Fifth Year in } \\
\text { NBA }\end{array}$ & & $\begin{array}{l}0.1584^{* * *} \\
(6.47)\end{array}$ & & $\begin{array}{l}0.1580^{* * *} \\
(6.46)\end{array}$ \\
\hline Constant & $0.4925^{* * *}$ & $\begin{array}{l}0.4309^{* * *} \\
10.64)\end{array}$ & $\begin{array}{l}0.4901^{* * *} \\
(9.73)\end{array}$ & $\begin{array}{l}0.4901^{* * *} \\
(8.81)\end{array}$ \\
\hline Adjusted $\mathrm{R}^{2}$ & 0.0761 & 0.3405 & 0.0711 & 0.3423 \\
\hline Observations & 613 & 613 & 613 & 613 \\
\hline
\end{tabular}

t-statistics in parentheses

*Significant at the 10-percent level

**Significant at the 5-percent level

***Significant at the 1-percent level 
Sunk Costs and the NBA, November 2013, p. 44

\begin{tabular}{|c|c|c|c|c|}
\hline \multicolumn{5}{|c|}{$\begin{array}{l}\text { Table X: Linear, Cubic, and Quinitic Estimates of Discontinuity Across Draft Rounds-Black Players } \\
\text { Only }\end{array}$} \\
\hline Variable & Linear -1 & Linear -2 & Cubic -1 & Cubic - 2 \\
\hline $\begin{array}{l}\text { Normalized Draft } \\
\text { Order }\end{array}$ & $\begin{array}{l}-0.0079 \\
(1.19)\end{array}$ & $\begin{array}{l}-0.0108^{*} \\
(1.96)\end{array}$ & $\begin{array}{l}-0.0118 \\
(0.18)\end{array}$ & $\begin{array}{l}-0.1399 * * \\
(2.33)\end{array}$ \\
\hline Normalized Order ${ }^{2}$ & & & $\begin{array}{l}-0.0100 \\
(0.64)\end{array}$ & $\begin{array}{l}0.0199 \\
(1.47)\end{array}$ \\
\hline Normalized Order ${ }^{3}$ & & & $\begin{array}{l}0.0012 \\
(1.13)\end{array}$ & $\begin{array}{l}-0.0008 \\
(0.92)\end{array}$ \\
\hline First Round Choice & $\begin{array}{l}-0.0319 \\
(0.69)\end{array}$ & $\begin{array}{l}-0.0826^{* *} \\
(2.11)\end{array}$ & $\begin{array}{l}-0.0017 \\
(0.02)\end{array}$ & $\begin{array}{l}-0.1369 * \\
(1.72)\end{array}$ \\
\hline $\begin{array}{l}\text { Interaction of Linear } \\
\text { Terms }\end{array}$ & $\begin{array}{l}0.0020 \\
(0.25)\end{array}$ & $\begin{array}{l}0.0026 \\
(0.40)\end{array}$ & $\begin{array}{l}0.0739 \\
(0.89)\end{array}$ & $\begin{array}{l}0.2066^{* * *} \\
(2.89)\end{array}$ \\
\hline $\begin{array}{l}\text { Interaction of } \\
\text { Quadratics }\end{array}$ & & & $\begin{array}{l}0.0220 \\
(1.13)\end{array}$ & $\begin{array}{l}-0.0034 \\
(0.21)\end{array}$ \\
\hline Interaction of Cubics & & & $\begin{array}{l}-0.0006 \\
(0.47)\end{array}$ & $\begin{array}{l}0.0018 \\
(1.57)\end{array}$ \\
\hline Shooting Guard & & $\begin{array}{l}-0.0164 \\
(0.66)\end{array}$ & & $\begin{array}{l}0.0171 \\
(0.69)\end{array}$ \\
\hline Small Forward & & $\begin{array}{l}0.0201 \\
(0.69)\end{array}$ & & $\begin{array}{l}0.0243 \\
(0.85)\end{array}$ \\
\hline Power Forward & & $\begin{array}{l}-0.0398 \\
(1.48)\end{array}$ & & $\begin{array}{l}-0.0311 \\
(1.17)\end{array}$ \\
\hline Center & & $\begin{array}{l}-0.0991^{* * *} \\
(3.29)\end{array}$ & & $\begin{array}{l}-0.0862^{* * *} \\
(2.86)\end{array}$ \\
\hline $\begin{array}{l}\text { Win Produced per } 48 \\
\text { Mins }\end{array}$ & & $\begin{array}{l}0.9219^{* * *} \\
(9.38)\end{array}$ & & $\begin{array}{l}0.9699 * * * \\
(9.95)\end{array}$ \\
\hline Lagged Winning Pct & & $\begin{array}{l}-0.0443 \\
(0.51)\end{array}$ & & $\begin{array}{l}-0.0623 \\
(0.73)\end{array}$ \\
\hline $\begin{array}{l}\text { Playoffs in Previous } \\
\text { Year }\end{array}$ & & $\begin{array}{l}-0.0350 \\
(1.25)\end{array}$ & & $\begin{array}{l}-0.0268 \\
(0.98)\end{array}$ \\
\hline $\begin{array}{l}\text { Playing for New } \\
\text { Team }\end{array}$ & & $\begin{array}{l}-0.0809 * * * \\
(3.44)\end{array}$ & & $\begin{array}{l}-0.0729 * * * \\
(3.14)\end{array}$ \\
\hline Foreign Player & & $\begin{array}{l}0.1212^{* *} \\
(2.44)\end{array}$ & & $\begin{array}{l}0.0967^{*} \\
(1.92)\end{array}$ \\
\hline Years of College & & $\begin{array}{l}-0.0059 \\
(0.85)\end{array}$ & & $\begin{array}{l}-0.0080 \\
(1.10)\end{array}$ \\
\hline Coach and GM & & $\begin{array}{l}0.0877^{* *} \\
(2.17)\end{array}$ & & $\begin{array}{l}0.0611 \\
(1.51)\end{array}$ \\
\hline Second Year in NBA & & $\begin{array}{l}0.0021 \\
(0.07)\end{array}$ & & $\begin{array}{l}0.0005 \\
(0.02)\end{array}$ \\
\hline Third Year in NBA & & $\begin{array}{l}0.0781^{* *} \\
(2.50)\end{array}$ & & $\begin{array}{l}0.0733^{* *} \\
(2.38)\end{array}$ \\
\hline Fourth Year in NBA & & $\begin{array}{l}0.1191^{* * *} \\
(3.73)\end{array}$ & & $\begin{array}{l}0.1120^{* * *} \\
(3.57)\end{array}$ \\
\hline
\end{tabular}


Sunk Costs and the NBA, November 2013, p. 45

\begin{tabular}{|l|l|l|l|l|}
\hline Fifth Year in NBA & & $\begin{array}{l}0.1687^{* * *} \\
(4.87)\end{array}$ & & $\begin{array}{l}0.1662^{* * *} \\
(4.89)\end{array}$ \\
\hline Constant & $\begin{array}{l}0.4528 * * * \\
(12.39)\end{array}$ & $\begin{array}{l}0.4435^{* * *} \\
(8.14)\end{array}$ & $\begin{array}{l}0.5088^{* * *} \\
(6.85)\end{array}$ & $\begin{array}{l}0.5998^{* * *} \\
(7.56)\end{array}$ \\
\hline Adjusted $\mathrm{R}^{2}$ & 0.0093 & 0.3712 & 0.0367 & 0.3989 \\
\hline Observations & 313 & 313 & 313 & 313 \\
\hline
\end{tabular}

t-statistics in parentheses

* Significant at the 10-percent level

**Significant at the 5-percent level

***Significant at the 1-percent level 